
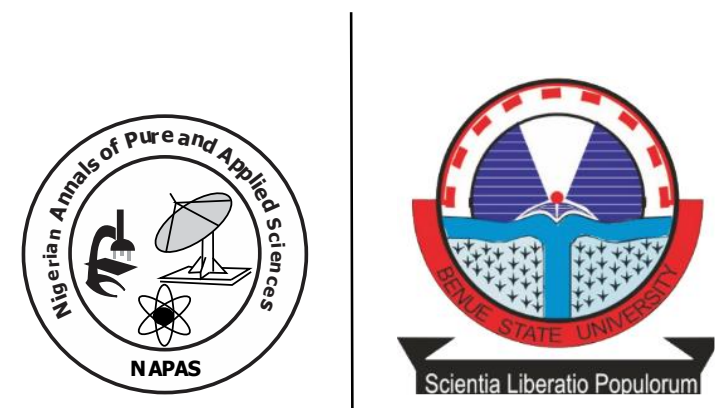

\title{
Pattern of Gully Characteristics under Different Land use Practices in Gboko Town, Benue State, Nigeria
}

\author{
lorkua, S. A., Aper J. A.* and Ayoosu, I. \\ Department of Geography \\ Benue State University, Makurdi \\ *corresponding author: jim_aper@yahoo.com +2348080815988
}

\begin{abstract}
As an outcome of landuse, soil erosion over the years has been a major problem in many parts of Nigeria especially in the urban centers including Gboko town where a lot of buildings generate runoff from roofs that alter the landscape morphology of the this hilly town. This study assesses gully morphometry in Gboko town with the aim to determine gully characteristics, compare the gully characteristics in the built up and un-built areas of Gboko town. Data was collected from the two major land use scenario areas through measurement and observations using stratified, purposive, and systematic sampling techniques. The data was analyzed using both the descriptive and inferential statistics including mean, standard deviation and tests of variability, correlation and student t-test. The results of the study indicate that the gullies in the built up areas of Gboko north, south, west and east were deeper $(0.6 \mathrm{~m}, 0.8 \mathrm{~m}, 0.5 \mathrm{~m}$ and $0.5 \mathrm{~m})$ and wider $(3.1 \mathrm{~m}, 4.6 \mathrm{~m}, 3.4 \mathrm{~m}$ and $3.4 \mathrm{~m})$ compared to the un-built areas of the town respectively. The result indicated that a significant difference exist in the gully elements between built-up and un-built areas except in the slope angle which is but similar between gullies in Gbokowest area. The study therefore recommends that further monitoring of actual gully erosion should be done under different building environments in the tow to achieve balance between urbanization, building construction, runoff and gully development to achieve sustainable urban land use and drainage control in the study area.
\end{abstract}

Keywords: Gully characteristics, Built-up and un-built areas, Land-use, Gboko town. 


\section{Introduction}

Gully erosion over the years has been a major problem in many parts of Nigeria especially in the urban centers including Gboko town. The effects and causes have been reported in different parts of Nigeria including South Eastern, South Western and North Central zones. Most of the studies conducted in respect of gully erosion in Nigeria like those of Ofomata, (1965 and 1978) in the South-Eastern Nigeria, Mbaya, Ayuba and Abdulahi (2012), Mbaya, (2013) in the Northern Nigeria, Iorkua and Kerenku (2010) in the North Central zone of Nigeria emphasized gully causes, effects and morphology. Less attention has been given to the impact of land use practices on gullies especially in Gboko town. A similar study was however, conducted by Iorkua in 2008 but in the North Bank area of Makurdi town and a single gully with varying land usepractices was considered. Many gullies under contrasting landuse practices were not considered as done by this study. Similarly,Iorkua and Kerenku (2010) studied the morphological characteristics of urban gullies in Benue state with emphasis on Otukpo and Makurdi while Gboko town was not part of their study area.

Even in Gboko town, a number of studies have been conducted on the gully incidence. Some of which include; Iorkyaa (2014) who studied the effects of gullies on infrastructural development with no interest on the effects of land use practices on gully characteristics, Kwaghga (2006) who studied the effect of gully erosion on land use in Gboko town without analyzing the impact of different land use practices on gully characteristics. Interestingly, Jika is currently carrying out a study on gully morphometry in Gboko town with no specific interest on the impact of different land use practices on gully characteristics. It is based on this research gap however, that the study is set to study gully characteristics in Gboko town under different land use practices so that, gully characteristics can be explained under different land use practices.

Different parts of Nigeria including Gboko town are affected by gully erosion and the effect has been reported by different researchers from different parts of Nigeria. Even as gullies persist in Gboko town under different land use systems, their characteristics and variations are not adequately studied. It is based on this background however that the study is set to compare gully characteristics under different land use practices in Gboko town. The study aimed at examining gully characteristics under different land use practices in Gboko town. This aim was achieved through the following objectives which include: to determine gully characteristics in the built up and un-built areas of the town, compare the gully characteristics in the built up and un-built areas of the town, establish and differentiate inter-relationships among gully characteristics in the built-up and un-built areas of the town, to examine the implication of the study on urban management in Gboko town.

The research findings have added to other studies conducted on gullies as geomorphic features in the area. The results are useful in urban planningand for creating awareness to help towards developing gully control measures in the town in respect to land use practices.

\section{Materials and Methods \\ The Study Area}

Gboko town is located between latitude $7^{0} 18^{\prime} 17^{\prime} \mathrm{N}$ and $7^{0} 23^{\prime} 37^{\prime} \mathrm{N}$ and longitude $8^{0} 47^{\prime} 07^{\prime} \mathrm{E}$ and $8^{0} 51^{\prime} 47^{\prime} \mathrm{E}$. The town which is located in part of the the Benue trough is overlain by cretaceous continental and marine sediments. The town is characterized by the combination of the pre-cambrian basement complex rocks and upper cretaceous sediments. The area is rich in sedimentary rocks, shell and sand stones (Abaa, 2004). The town is dominated by ferruginous soils and the texture ranges from sandy to loam. In many locations, the soils are coarse-loose sand with lesser aggregate stability. The soils are predominately deep sandy. The dominance of sand particles decreases the influence the clay fraction may have on the physical and chemical parameters thereby decreasing its erodibility, (Nyagba, 1995).

Gboko town experiences tropical wet and dry climate (Koppen's Aw). The town experiences two major seasons; rainy and dry seasons from late April-October, and Octoberearly April respectively with mean annual rainfall of about $1000 \mathrm{~mm}-1300 \mathrm{~mm}$. The seasonal rainfall distribution in the area is unimodal with the highest rainfall occurring in 
August and September (Tyubee, 2010). Temperature of the area is generally high during the day throughout the year. The two periods of temperature peaks in the area are lately March and early April and ranges between 25.95 to $30.0^{\circ} \mathrm{C}$. The relative humidity experienced in the area is higher during wet seasons and low during dry season. The study area receives abundant sunlight due to its location in the tropics. This also influences the conventional type of rainfall experienced in the area. Gboko town is situated within guinea savannah and its vegetation is characterized as that of places within the zone. But as a result of human interference with the environment including urbanization, the natural vegetation of the area has almost disappeared with only few natural plants species seen in some un-built portions within the area. The common plant species found in the built up areas of Gboko town are artificially planted including mangotrees of different species, pawpaw, cashew, guava, gmalina, and carpet grasses. The drastic change in the natural vegetation of the area is equally attributed to the land use change from peasant agriculture to settlement.

However, the un-built areas of the town contain farms cultivated of different crops including yam, cassava, groundnut, vegetable and sweet potatoes. The un-built up areas also have a host of some natural vegetation especially shrubs and grasses of different species which also serve as surface protectors in the area especially on the hilly slopes. Gboko town is an area with gentle undulating landscape and hilly in the northern part of the town. The prominent upland in the area has an elevation of between 120m-200m above sea level (Terna, 2008). The town is drained by several seasonal streams including Kontyen, Nguembi, Undulan, Kamkigh, and Aungwa streams. Some of these streams like Nguembi and Aungwa are greatly affected by stream bank erosion.

There are also a number of artificial drainages constructed throughout the town. However majority of the drainage channels constructed are silted up by sand and waste products generated from households in the area.

Figure 9: Histogram of Plain, Scrambled and Encrypted colour image of mandril using Aizawa chaotic image encryption scheme.

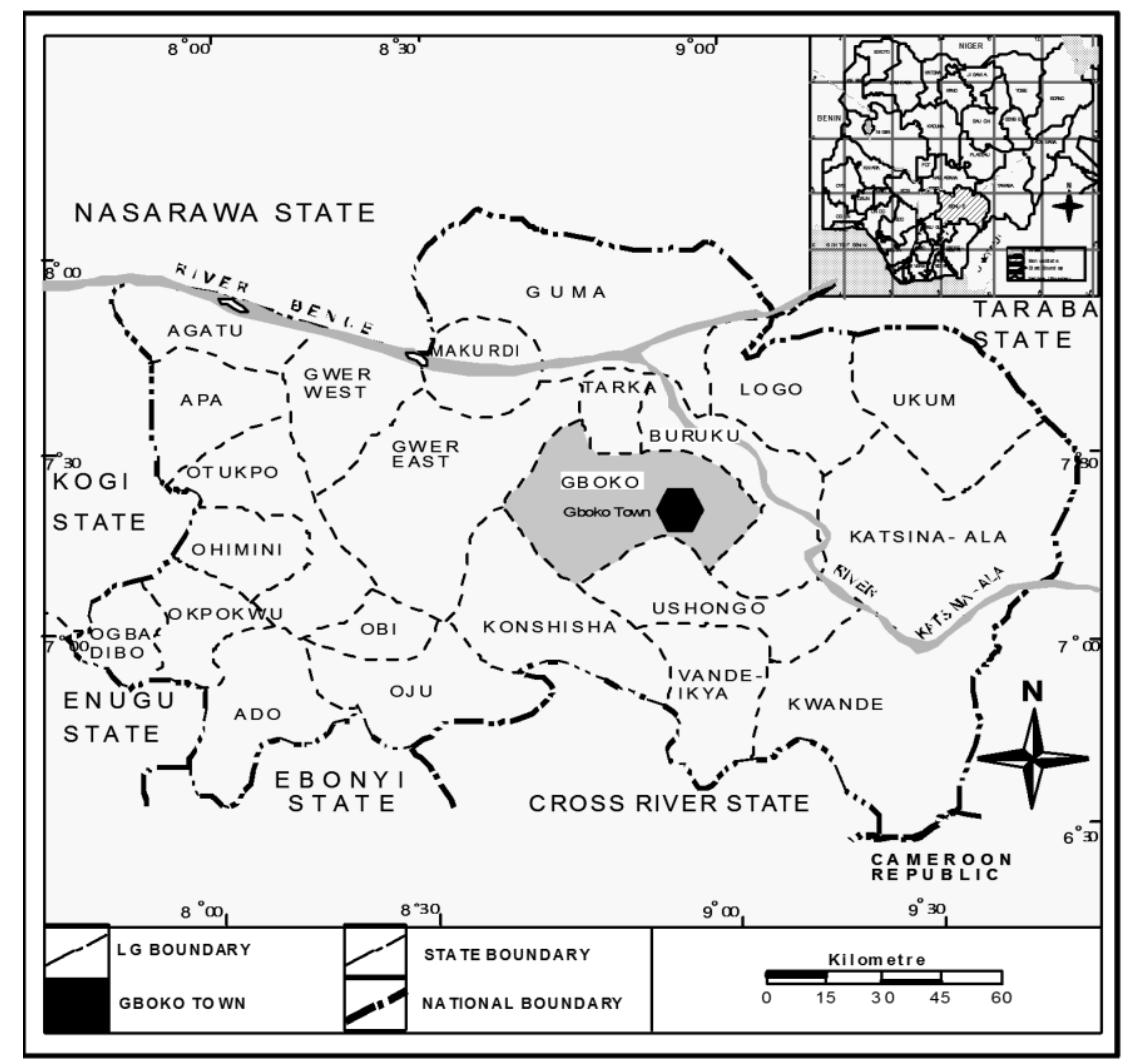

Figure 1: Benue State showing Gboko Local Government Area

Source: Adapted from Benue State Ministry of Lands and Survey, 2017 


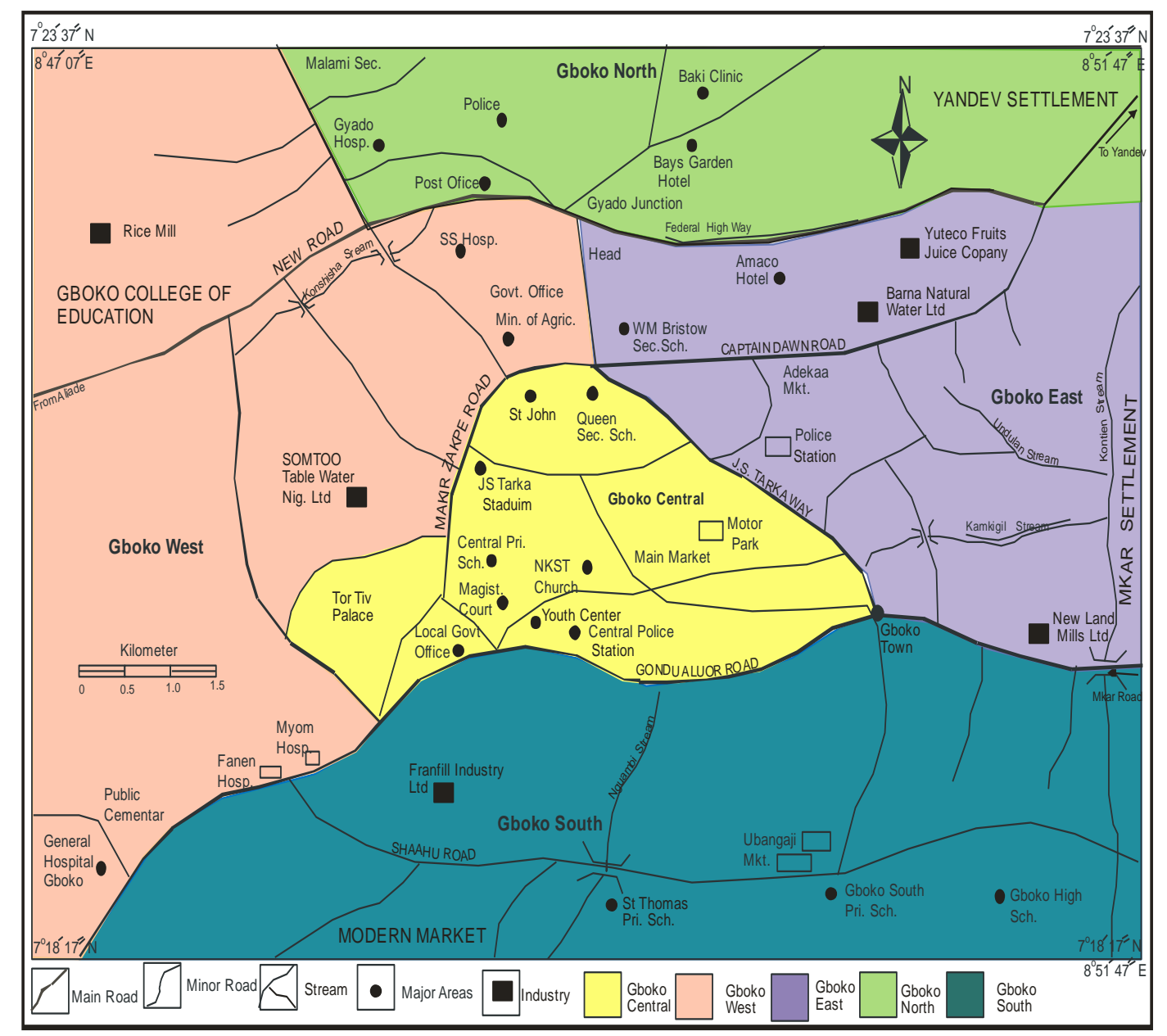

Figure 1.2: Map of Gboko Town Showing Functional Units Source: Ministry of Lands and Survey Makurdi (2016)

The major land use practice in Gboko town is building of houses for residential and other specific purposes. The place is also made of un-built plots some of which are used for agricultural activities while others are left bare uncultivated covered by vegetation of different kinds. Thus the study considered gully characteristics under two major land use patterns: built up and un-built areas in Gboko town. The major land use types in the built up areas of Gboko town consisted of houses, roads, streets, culverts and few drainage channels however, the un-built land use types is made of undeveloped plots, farm lands, and some thick forested reserved area. Other land use practices in the area include, rice milling, which is located in southern part of the town, mechanic site, located in the northern part of the town, minor industries and other socio-economic institutions including schools, hospitals, markets, guest houses and service stations. There are also some mining activities that take place in the town. Sharp sand is mined occasionally along the major streams in the area like Nguembi while plaster sand is mined in the swampy areas of the town. Stones are also mined at large scale around the Gboko hills. These resources also serve as building materials that contribute to the land use change in the area. Gboko town is also made of streets that connect one part of the town and the others however, majority of the streets are worn away while some are completely cut off by gully erosion. This is mostly common in the eastern part of Gboko town where there are many streams associated with stream bank erosion.

\section{Data Collection and Analysis}

Data was collected elicit information on the differences in gully characteristics and the nature of relationships among the gully characteristics between the built up and un-built areas of the town. This study adopted observation and field measurement to collect data on gully characteristics covering including, length, shoulder and bed widths, depth and slope angle in the study area. The study sample comprised of 8 gullies selected among the 26 gullies in Gboko town. Stratified sampling technique was considered in the first instance to 
select eight out of the twenty six most prone gullies within the town. Purposive sampling technique was then used to select two (2) gullies from each of the considered functional (built up and un built) units of the town on the basis of the most intensive gullies identified during reconnaissance survey making up the sum of eight (8) gullies in the study area(Table 1).

Table 1: Selected Gullies in Built-up and Un-built Areas of Gboko town

\begin{tabular}{|c|c|c|c|}
\hline $\mathbf{S} / \mathbf{N}$ & Location & Built up Area & Un-built Areas \\
\hline 1 & Gboko North & $\begin{array}{l}\text { Adi street Behind Government Day } \\
\text { Secondary School. }\end{array}$ & Beside Mectan Secondary School \\
\hline 2 & Gboko South & Behind St Thomas Primary School & Behind Gboko High School. \\
\hline 3 & Gboko East & Usaka street & Beside New Land Mills. \\
\hline 4 & Gboko West & Agaswa street & Behind Gboko College of Education \\
\hline
\end{tabular}

Source: Author's Field Survey, 2016.

Systematic measurement was therefore used to collect data on the gully characteristics. The gully characteristics of depth, bed and shoulder widths, length, and slope angle were measured at 10 meter interval along each sampled gully channel. This interval was determined because of the meandering and marked difference in the gully's widths and depths as observed during reconnaissance survey. The characteristics of gullies under each area in every location was analyzed while the inter relationship and comparison was made among their characteristics. The collection of data through measurement took the following procedures as described by Songu, Oyatoyo and Iorkua, (2015).

The data for this study was analyzed using descriptive and inferential statistics including mean, standard deviation, co-efficient of variation Pearson's product correlation moment and student t- test. Co-efficient of variation and student $t$ - test were used to compare data collected from the two different land use practices (build up and un-built areas) to find out whether or not a significant difference exists in the gullies measured from the two land use practices. Pearson Product Moment correlation on the other hand was used to test the relationship existing among the gully characteristics of depth, bed and shoulder widths, length, and slope angle in both built up and un-built areas of the Gboko town. The results computed from student t-test and Pearson's product moment correlation was tested at 0.05 significance level.

\section{Results and Discussion}

\section{Gully Patterns in Nighbourhoods in Gboko Town.}

The built-up areas of Gboko town comprises of houses, roads, culverts, and drainage channels and recreation. The area is made of streets that connect one part of the town and the others. However, most of the streets are not presently easily accessible because of their poor state resulting from gullies. Many streets, houses and fences are affected by gully erosion as many either gullies run parallel, across and along streets and buildings arising from the hilly nature of the town. Moreover, most of the drainage channels are not well completed and hence paved ways for many gully initiations. However, the un-built areas of Gboko town comprise mainly of the empty plots of varying sizes some of which are used for cultivation of crops like tomatoes, maize, yam, and cassava while other areas especially in the north and east of Gboko existed as reserved areas consisting of thick vegetation including palm trees, thick, gmaglina and mango trees. Most of the gullies in the un-built areas are highly sinuous due to obstructing materials including shrubs, plant roots and uncompleted and abandoned/dilapidated structures including fences.

The result of 4 gullies measured from the built up areas revealed that all the gullies are short ranging from $40 \mathrm{~m}$ to $80 \mathrm{~m}$. The depth of the gullies ranges from 0.8 to $3.8 \mathrm{~m}$ with the deepest point found with the gully in Gboko north. The gully bed width on the other hand ranges from 
9.8 to $24.3 \mathrm{~m}$ while the gully shoulder width ranges from 18.3 to $36 \mathrm{~m}$. The slope angle of gullies under this land use practice varies from 1 to $5^{\circ}$. The gully in Gboko north lies along Adi Street, evidently initiated as a result of the failed drainage attempts where a culvert was constructed without proper linkage to the drainage channel. The gully empties at Aungwa stream and the gully bed is littered with sand stones that results to a rough gully bed and walls. The presence of resistant materials (strong sand stones and clay) at the gully banks and bed at varying intervals results in the irregular depth and width of the gully. The gully has the total length of $50 \mathrm{~m}$ and the mean depth of $2.7 \mathrm{~m}$, its bed and shoulder widths have means of $13.6 \mathrm{~m}$ and $21.9 \mathrm{~m}$ respectively with a mean slope of $2.5^{\circ}$.(Figure 3-6). The gully measured in Gboko South lies behind St Thomas primary school and is believed to have resulted from the steep slope adjacent to Kamkigh stream. The gully head is dominated with gully bed materials like stones, blocks and waste however, the gully mouth lies in the Kamkigh stream with smooth gully bed. The gully has the total length of $40 \mathrm{~m}$ and the mean depth of $2.5 \mathrm{~m}$ while its bed and shoulder widths have the means of $13.5 \mathrm{~m}$ and 27.2mrespectively. The gully slope angle on the other hand has the mean of $2.4^{\circ}$. The standard deviation and coefficient of variation computed from the gully from the built up areas of Gboko South show the values of 0.72 and 28.8 respectively for gully depth. The gully bed width indicated the standard deviation of 3.3 and the coefficient of variation of 24.4. Similarly, the gully shoulder width measured of this gully show 2.9 and 10.6 as standard deviation and coefficient of variation respectively. The gully slope angle measured here indicated the values of 1.5 and 0.63 for standard deviation and coefficient of variation respectively.

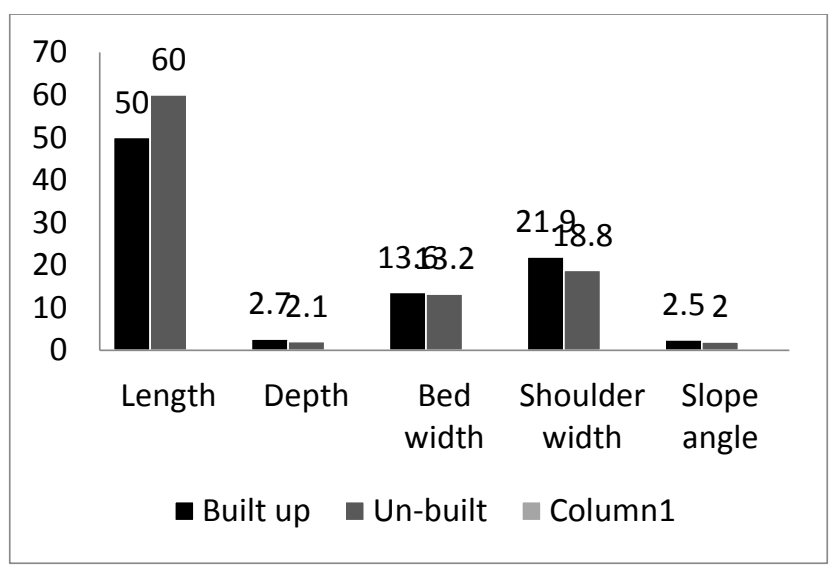

Figure 3: Gully Elements in the Built and Un-Built Areas of Gboko North

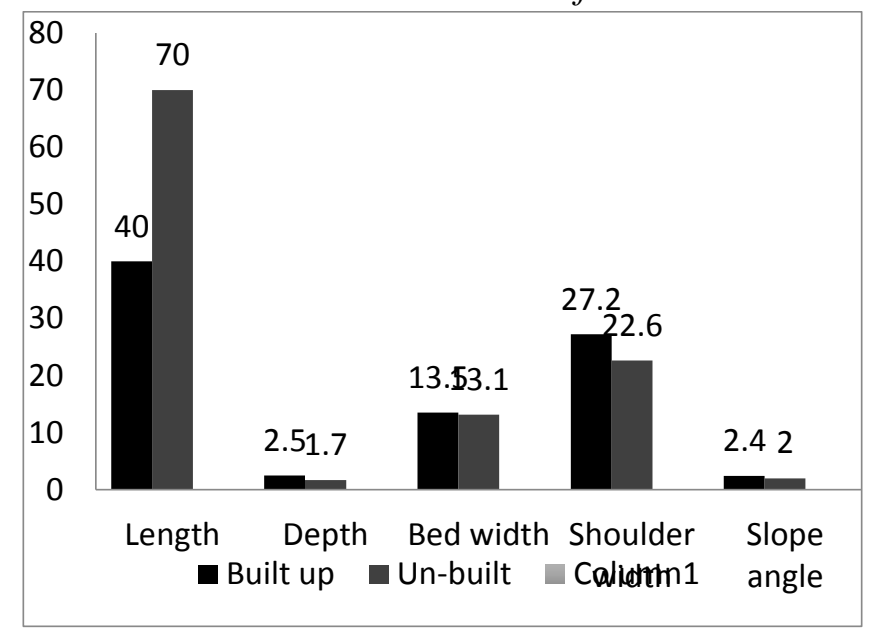

Figure 4: Gully Elements in the Built and Un-built Areas of GbokoSouth 


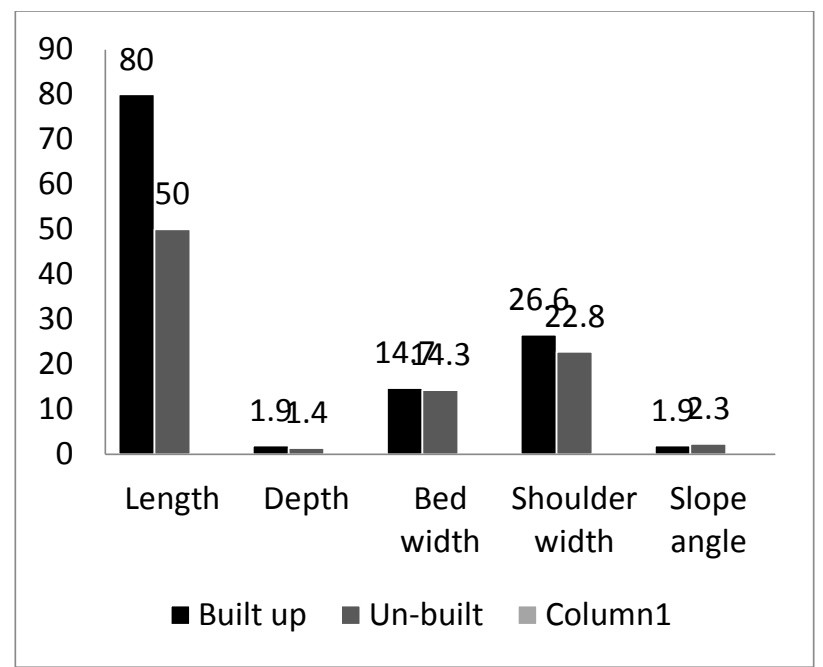

Figure 5: Gully Elements in the Built and Un-built Areas of GbokoWest

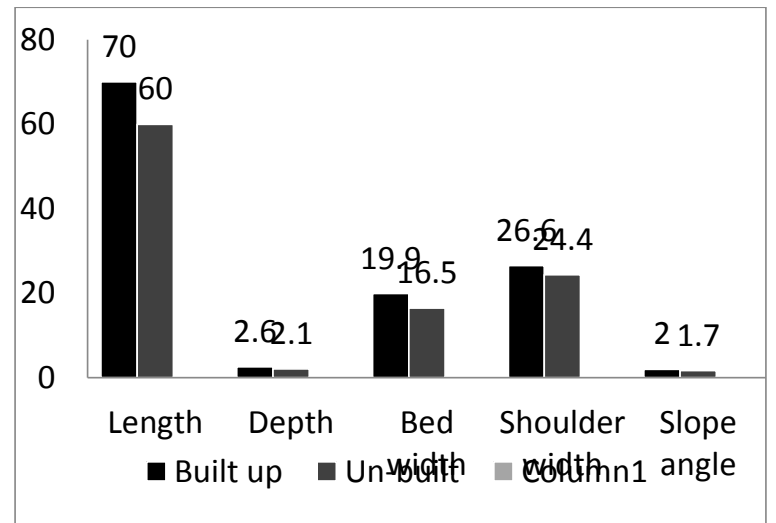

Figure 6: Gully Elements in the Built and Un-Built Areas of Gboko-East

The gully studied beside Myom Hospital in Gboko-West evidently resulted from poor drainage management along Agaswa Street. The gully cut across the street at the extreme end making it un- motorable. The gully mouth lies in the Kamkigh stream with moderate bed and shoulder widths. The gully is longer $(70 \mathrm{~m})$ than the gullies measured in the Gboko North $(50 \mathrm{~m})$ and South $(40 \mathrm{~m})$ with the mean depth of $2.6 \mathrm{~m}$ while the bed width, shoulder widths and slope angle averaged $19.9 \mathrm{~m}, \quad 26.6 \mathrm{~m}$ and $2^{\circ}$ respectively. The standard deviation and coefficient of variation for the gully characteristics measured in Gboko West indicate the values of 0.73 and 27.0 for depth, 3.0 and 15.8 for bed width 5.1 and 19.2 for shoulder width and 1.1 and 19.2 for slop angle respectively.

The gully measured in Gboko East lies along Usaka Street and parallel to St Francis Parish fence. It threatens the fence of the premises and made the street un-motor-able. The gully initiates as a result of the failed drainage attempts. The presence of resistance materials especially hardened and compacted sand stones however, help to control the gully wall recession (widening) and deepening. The gully terminates by a fence and sand banks mounted by the residents of the area which as serve as obstruction. However, the gully was the longest (80m) among the gullies measured in the built up areas of the town. The gully has the mean depth of $1.9 \mathrm{~m}$ and the mean bed and shoulder widths of $14.7 \mathrm{~m}$ and $26.6 .4 \mathrm{~m}$ respectively. This gully has the mean slope angle of $1.9^{\circ}$. Moreover, the computed values of standard deviation and coefficient of variation for gully characteristics in Gboko East indicated 0.8 and 36.8 for gully depth, 4.7 and 31.9 for bed width, 5.5 and 23.5 for shoulder width and 0.78 and 41.1 for slope angle respectively.

The gullies studied under built up areas does not have uniform depth, bed width, and shoulder width as shown by their measures of central tendency. Three of the four gullies measured under this land use practices have mean depths of $2.5,2.7$ and 3.5 meters. The shallowest points along these are the gully head of the gully in Gboko North (1.6m) and the gully tail of the gully in Gboko East $(0.8 \mathrm{~m})$. In terms 
of width (bed and shoulder widths), the gully along Usaka street beside St Francis Parish, Gboko East have broader bed width of 24.3 while that of Gboko west have broader shoulder width with the widest point of $36 \mathrm{~m}$. The gully from Gboko South is however shallow $(0.8 \mathrm{~m}$ -
$2.9 \mathrm{~m})$ but the longest gully within the area (80m).

The further description of the gully in the built-up area of Gboko town was done based on the observations made during data collection presented on Plate1.

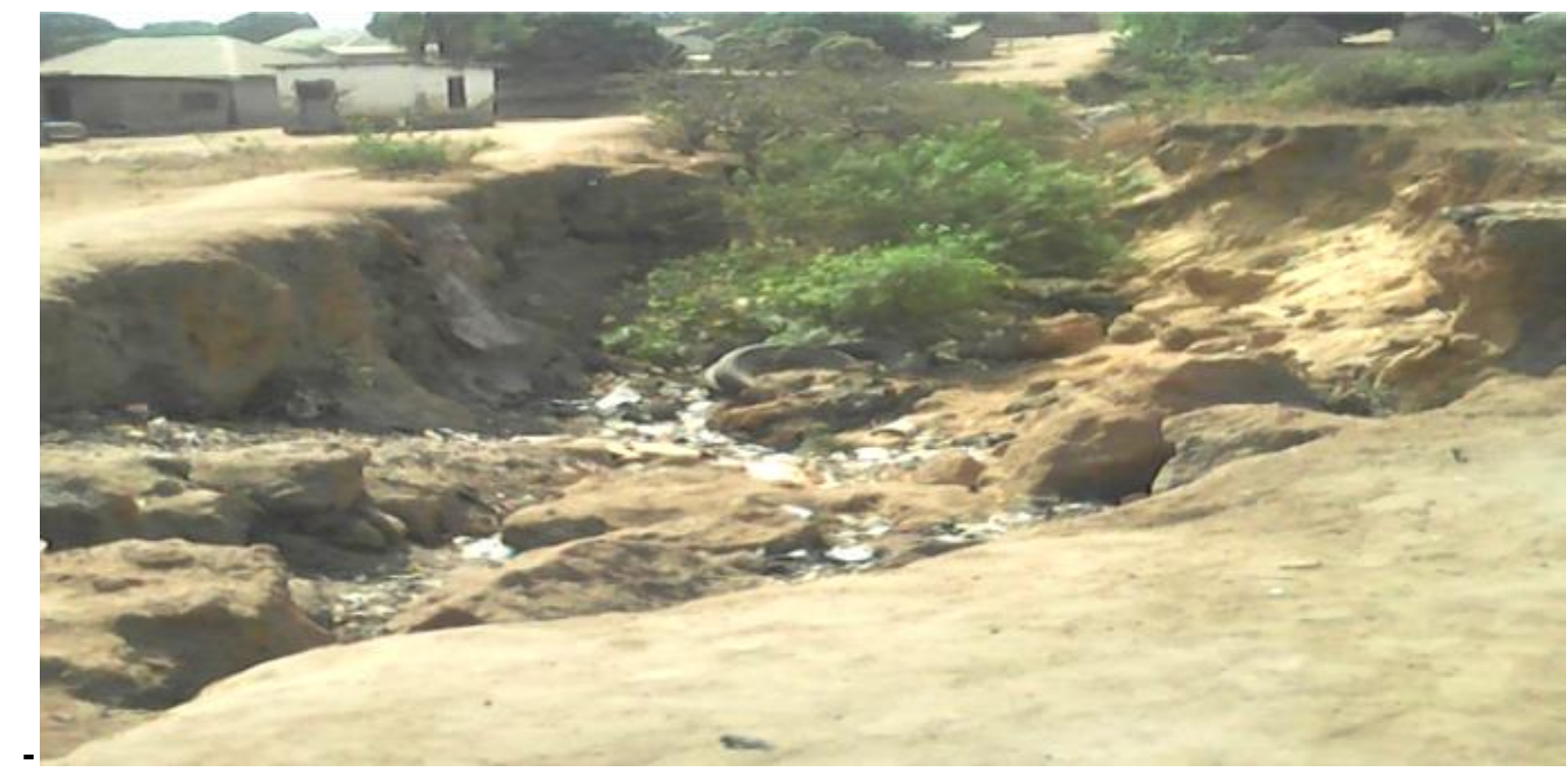

Plate 1: A typical gully head in a built-up area (St. Thomas Primary School) in Gboko: Note: The gully wall recession and presence of waste materials in the gully channel. Photo by: The Authors, January, 2017.

The gullies from the built up areas of Gboko town as observed during data collection show distinct characteristics with wider bed and shoulder widths. The gully in Gboko North and East were observed to have dominated with resistance materials of different nature including hardened sandstones which give rise to varying depth and width along the gully course. There were also evidence of diverse gully control measures put in place by the residence to reduce the gully effects including the planting of bamboo trees and banana trees. Culverts and buildings were also observed to be exposed and out crust as the surroundings were washed away by gully erosion. The gullies from the south and east of Gboko indicated active gully processes at the banks as wider wall recession is observed of the gullies resulting to wide gully shoulder widths. This implies that there are more resistance materials in the sub soils in the area than in the top soils. The gullies observed in these areas have their beds inflicted with different waste materials generated from households including polythene, package water bags, yam peels as well as stones, pebbles and rock fragments of different sizes. All the gullies observed from this land use practice have posed a great threat to the buildings like St Francis Parish fence (Gboko East), Mr. Akaangee's house (Gboko south) as can be seen on Plate1.

In contrast, the gully studied from the unbuilt area of Gboko north exists behind Mectan School just beside a bridge across New Road. The gully is a threat to new road and is almost cutting off the high way. The gully initiates in a depressed point that receive surface run off from either sides of the road while the compressed materials used in road construction, depressed nature of the area has made the action of water to be very active at the gully head. The presence of thick vegetation however limits the actions of water at the gully banks along the gully course thereby reducing the gully banks collapsing. The gully is highly sinuous but shortly joins the tributary of Aungwa stream which marks the gully mouth. The result revealed that the gully from Gboko North has the mean depth of $2.1 \mathrm{~m}$. The bed and shoulder widths have their 
respective mean of $13.2 \mathrm{~m}$ and $18.8 \mathrm{~m}$. The gully indicated the mean slope angle of $2^{\circ}$. The gully in the un-built areas of Gboko south initiated in an empty plot along a failed drainage channel constructed to control gully in the other neighboring plot. The gully channel is covered in the either sides by thick shrubs of different species that help to check the gully wall collapsing. There are also some plant species like oil palm and bamboo trees found along the gully course. The gully however, has its mouth in Nguembi stream.

The characteristics of the gully studied in Gboko south based on the result have the mean depth of $1.7 \mathrm{~m}$ and the mean shoulder and bed widths of $13.1 \mathrm{~m}$ and $22.6 \mathrm{~m}$ respectively. The gully slope angle on the other hand averaged $2^{\circ}$. An examination of the deviation among the gully characteristics also indicated higher deviation in the gully bed (3.6) and shoulder widths (5.2) than the gully depth (0.49) and slope angle (0.9). This gully was however, the longest gully measured in the unbuilt areas of the town with the gully distance of $70 \mathrm{~m}$. The gully in the unbuilt areas of Gboko west initiated as a result of the depressed which serve as a reception zone for surface runoff in the area. The gully head and mouth were however narrower than the middle course. The gully course cut across shrubs and plant cover which moderates the gully processes at the banks. The analysis of data on gully characteristics measured in Gboko West indicated the mean of $2.1 \mathrm{~m}$ for depth, $16.5 \mathrm{~m}$ for bed width, and 24.4 for shoulder width and $1.7^{\circ}$ for slope angle. The deviation among the gully characteristics based on the computed standard deviation was also higher with bed width (2.2) and shoulder width (4.0) than gully depth (0.48) and slope angle (0.90).

Moreover, the gully studied in the unbuilt area of Gboko east was a very short gully that lies beside Newland mills. The gully mouth runs shortly in the Nguembi stream with a relatively uniform depth, shoulder width but varying bed width along the course. The gully indicated the mean of 1.4 for depth, $14.3 \mathrm{~m}$ for bed width, $22.8 \mathrm{~m}$ for shoulder width and $2.3^{\circ}$ for slope angle. Testing the level of deviation of the gully characteristics in this area, the results from the computation of standard deviation indicated the value of 0.4 for gully depth, 4.4 for bed width 2.2 for shoulder width and 0.8 for slope angle respectively.

Generally the gullies measured from the un-built areas of Gboko town exhibit distinct characteristics. Two of the gullies measured from this land use practice have the mean depths of $2.1 \mathrm{~m}$. However, the detail examination of the individual gullies revealed that the gullies have the depth of up to $3.2 \mathrm{~m}$ as the deepest point as seen with the gully in Gboko north. The shallowest points among these gullies are the mouth and the head of the gully in Gboko east with the depths of $0.7 \mathrm{~m}$ and $1.2 \mathrm{~m}$ respectively. The gully is the shallowest but still the longest gully measure in the area, In terms of width, the gully in Gboko west has broadest bed $(23.1 \mathrm{~m})$ and shoulder widths $(30.9 \mathrm{~m})$. It is the largest gully measured from the unbuilt areas of Gboko town.

The observations made of the gully from the un built areas of Gboko North presented on Plate 1, indicated that the gully exhibit no defined pattern of depth with moderate bed and shoulder widths. The gully banks are covered by plants of different species like thick and gmalina which serve as shear strength protecting gully banks from collapsing. The gully from Gboko south has its banks and floor covered by grasses and shrubs of different species. However, one of the banks was cleared for farming purpose. Finally, an observation made of a gully in the un built areas of Gboko east also have dominant species of shrubs and plants cover moderating gully process along the gully course

Generally, the gullies in the un-built areas of Gboko town as observed are short with steeper slope angle, no defined pattern of depth increase or decrease and are highly associated with abundant vegetal cover at the banks that moderates their processes under this land use practice. The collective observation made from the gullies under built up and un-built land use practices of Gboko town revealed that all the gullies in Gboko town are short and most of them have their rise from nearby streams. In addition the gullies in the built up areas of Gboko town were dominated with waste materials discharged from households. This contributes to the gully wall recession. Most of the gullies in these areas serve as waste dump sites for the neighboring houses. In contrast, the gullies in the un-built areas have some vegetal 
materials like plants, grasses and shrubs at their banks which help to checkmate the collapsing of the gully banks. This conforms to Gordon's (2008) findings that land use practices associated with vegetal materials promotes stability in gully channel thereby moderating the gully characteristics. However, some of the gullies in the un-built areas of the town also have waste materials discharged from households, transported by water and held by gully wall and other channel materials as also noted by Faniran and Areola (1974) as factors responsible for irregular gully shapes.

\section{Comparison of Gully Characteristics in Gboko town}

The gullies studied from the built up and un built areas of Gboko town exhibit distinct characteristics. The examination of their central tendency and dispersion through mean, standard deviation and coefficient of variation revealed that most of the gullies in the built up areas were wider and deeper than the gullies in the un- built areas. The gully studied in the built up area of Gboko East for instance measured $80 \mathrm{~m}$ long while the deepest gully was also in Gboko North is $3.8 \mathrm{~m}$. The gullies with wider bed $(24 \mathrm{~m})$ and shoulder $(36 \mathrm{~m})$ were also found in the built up areas of Gboko town. The deepest gully from the un-built areas measured $3.2 \mathrm{~m}$ with the widest bed gully as $23.1 \mathrm{~m}$ and the broadest point at the shoulder width was measured $30.9 \mathrm{~m}$. This implies that gullies from the built up areas of Gboko town are more deep and wide as compared to those from the un-built areas.

The further comparison of gully characteristics from the two major land use practices of Gboko town was done using student $t$ test (Table 2) at 0.05 level of significance. The gully depths, measured from the two distinct land use practices of Gboko town have differences that are significant. The result indicated that a significant difference exist in the gully elements between built-up and un-built areas except in slope angle which is only similar in Gboko-west area.

Table 2:Difference in Gully Characteristics in the Built-up and Un-built Gboko Town.

\begin{tabular}{|c|c|c|c|c|c|}
\hline Location & $\begin{array}{l}\text { Gully } \\
\text { Characteristics }\end{array}$ & Computed $t$. & $\begin{array}{c}\text { Degree of } \\
\text { freedom }\end{array}$ & $\begin{array}{l}\text { Table } \\
\text { value }\end{array}$ & Decision \\
\hline Gboko & Depth & 2.50 & 11 & 2.20 & significant \\
\hline \multirow[t]{3}{*}{ North } & Bed width & 2.31 & 11 & 2.20 & significant \\
\hline & Shoulder width & 2.52 & 11 & 2.20 & significant \\
\hline & Slope angle & 1.13 & 11 & 2.20 & not significant \\
\hline Gboko & Depth & 2.22 & 11 & 2.20 & significant \\
\hline \multirow[t]{3}{*}{ South } & Bed width & 0.21 & 11 & 2.20 & significant \\
\hline & Shoulder width & 2.27 & 11 & 2.20 & significant \\
\hline & Slope angle & 0.52 & 11 & 2.20 & significant \\
\hline Gboko & Depth & 2.33 & 13 & 2.16 & significant \\
\hline \multirow[t]{3}{*}{ West } & Bed width & 2.60 & 13 & 2.16 & significant \\
\hline & Shoulder width & 2.58 & 13 & 2.16 & significant \\
\hline & Slope angle & 0.59 & 13 & 2.16 & not significant \\
\hline Gboko & Depth & 3.80 & 13 & 2.16 & significant \\
\hline \multirow[t]{3}{*}{ East } & Bed width & 2.26 & 13 & 2.16 & significant \\
\hline & Shoulder width & 2.23 & 13 & 2.16 & significant \\
\hline & Slope angle & 0.93 & 13 & 2.16 & not significant \\
\hline
\end{tabular}

Decision: Significant if calculated $\mathbf{t}>\mathbf{2 . 2 0}$, or 2.16 at 0.5 confidence level:

Source: Authors field work, 2017.

\section{Conclusion}

The study considered two land use practices; built up and un-built in Gboko town. The built up areas consist of varying land use types including roads, houses, streets and culverts that have influenced the gully characteristics in various ways. The un-built areas on the other hand are associated with land use types like farming and vegetation cover. The land use types like roads, streets and building in 
the built up areas of Gboko town have impact on gully characteristics like gully length, depth and width. Most of the gullies in the built up areas of Gboko town are initiated as a result of poor drainage management in the area. Land use types like roads and streets indicated greater impact on the gully head and length. Most of the gullies under this land use practice lie parallel and along the streets and fences in the area.

Also land use types including building have influenced gully characteristics like bed width, gully slope and even depth as gully processes were interrupted through buildings and varying control measures adopted by house mowners resulting to gully wall collapsing and gully depth increase at some points along the gully course. The land use type in the un-built areas of Gboko town is dominated with vegetation which moderates the gully processes and the characteristics of gullies like gully shoulder widths and slope angle. Besides the dominance of vegetation at these areas act as surface cover and hence moderates the gully depth and width.

Moreover, the gully characteristics from the built up and un-built land use practices of Gboko town show greater variation in their characteristics including depth, shoulder width, and bed width indicating deeper and broader gullies in the built up areas than the un built areas.

Built up areas in Gboko town is increasing with a proportionate decrease in unbuilt areas. An expansion in built up area into bare lands and a decrease in surfaces with vegetal covers are major drivers of gully erosion which is affecting Gboko town. If the present scenario continues, then gully erosion activity will continue. Therefore there is a need for comprehensive land use planning and management in Gboko town for effective rehabilitation of the gully and also reduce threats to livelihoods. Monitoring of actual gully erosion should be done under different land uses practices in the study area in order to determine hot spots for effective land use strategies.

\section{References}

Abaa, S.I (2004).Origin of the Benue Trough and its Economic Significance to Nigeria. The Second Inaugural Lecture of Benue State University, Makurdi Benue State.
Faniran, A. and O. Areola (1974)" Land-Form Example from Nigeria. A Gully", Nigeria Geographical Journal, Vol.17, No1. Pp 57-60

Gordon, L.M (2008). Modeling Long Term Soil Loss on Agricultural Fields Due to Ephemeral Gully Erosion. Journal of Soil and Water Conservation Vol. 63 No. 4, pp173-181.

Iorkua S.A. and Kerenku T.A. (2010). Morphological Characteristics of Urban Gullies in Benue State. A Paper presented at the Association of Nigerian GeographersNational Conference held at University of Abuja, Nigeria.

Iorkua, S.A. (2008). AComparison of Gully Properties under Different Land use Systems in Makurdi. Journal of Geography and Development. Vol.2 (1) Pp. 116-126

Iorkyaa, A. (2014). The Effects of Gully Erosion on infrastructures in Gboko Town. A Dissertation Submitted to the Department of Geography, Benue State University, Makurdi.

Kwaghga, D.D. (2006). The Effects of Gully Erosion on Land use in Gboko Town. Benue State, Nigeria. M.Sc. Tthesis submitted to the Department of Geography, Benue State University, Makurdi.

Mbaya, L, Ayuba, H, and Abdullahi, J.(2012). An Assessment of Gully Erosion in Gombe Town of Gombe State, Nigeria. Journal of Geography and Geology. Vol. 4, No. 3.pp. 110-121.

Mbaya, L.A (2013). A Study of Interrelations among Gully Variables in Gombe Town, Gombe State, Nigeria. Wudpecker Journal of Geography and Regional Planning Vol. 1, No. 1 pp. 001-006.

Nyagba, J.L (1995b) Soils of Benue State in D.J Denga (Ed) Benue State the Land of General Potentials; a Compendium. Calabar: Rapids Educational Publishers Ltd.

Ofomata, G.E.K. (1965). Factors of Soil Erosion in Enugu Area of South Eastern Nigeria. Nigerian geographical Journal Vol. 8 No. 1 pp. 33-44.

Ofomata, G.E.K.(1978) Man as a Factor of Soil Erosion in South Eastern Nigeria Journal of Tropical Ecology, Vol. 2 No. 2, pp. 143-154.

Songu, G.A, Oyatoyo, K.T and Iorkua, S.A (2015). Impact of Gully Erosion on Stream Sedimentation in Demekpe Drainage Basin. American Journal of Water Resources, Vol. 3, No. 4 Pp 100-108. 
Terna, S. (2008).Waste Generation and Management in Gboko Town, Benue State Nigeria. M.Sc Thesis submitted to Department of Geography, Benue State University, Makurdi.
Tyubee, B.T (2010).An Assessment of Vulnerability to Climate Change Riskin Makurdi Nigeria, Doctor Fellowship Report. Makerere University, Kampala Uganda. 